\title{
·高齢社会での労働環境づくりに関する基礎的な調査 FUNDAMENTAL SURVEY ON IMPROVING OCCUPATIONAL ENVIRONMENTS IN THE RAPIDLY AGING SOCIETY
}

\author{
永田久雄*, 李 善 永**, 佐々木 昭彦*** \\ Hisao NAGATA, Sunyoung LEE and Akihiko SASAKI
}

\begin{abstract}
The elderly population increases rapidly while younger population becomes decreasing year by year in Japan. People over 65 years old are estimated to reach over $27 \%$ of population by the year 2025 . In order to facilitate the participation of elderly individuals and to integrate them with other generations in the rapidly aging society, we need various strategies to solve social problems. The present occupational environments are not always fit to elderly workers. It is an urgent issue that we should redesign occupational environments regarding physical and mental deterioration of elderly people.

370 elderly workers over 60 years-old and 430 workers from 40 to 49 years-old completed questionnaires. Questions were done about preferred age-group to work with, major concern of elderly capability to work with, major desired design to extend elderly employment, concerns to their working environments, own physical deterioration etc. Fundamental design concept in occupational environments based on symbiotic relations is discussed in this paper.
\end{abstract}

Keywords: aging society, elderly worker, baby boomer, occupational environment, symbiotic relation 高踰社会, 高齢労働者, 団塊の世代, 労働環境, 共生関係

\section{1. 緒言}

総人口に対して 65歳以上の高龄者人口の占める割合は, 1920年 〜 1950年までの 30 年間は約 $5 \%$ で推移していたが, その後の約 50 年間は年々漸增し 1998 年には $16 \%$ に達し，2025年には $27 \%$ にな ると推定されている3)。それにともない, 労働人口も急速な勢いで 高齢化しており，その変化に対応した労働睘境や労働形態の新たな 構築が模索されている。21世紀の超高齢社会に備え, 働く意思の ある高齢労働者に配慮した労働環境づくりが強く求められている。 そのためには高跉労働者を受け入れる社会的合意と職場改善のため の技術的方法論の確立が緊急課題となっている。

21 世紀に直面する高齢者問題は団塊の世代（1947年～1949年生 まれ）の問題である。1981年〜1996年までの実質貨金の伸び率を 見てみると, 団塊の世代が最も低(4)。現在, 団塊の世代を中心 とした中高年労働者がリストラの対象となっており, 年金・健康保 険制度を支えてきた世代が, 将来, 制度の存続そのものの危機に直 面し, 現在の高秢者より経済的に恵まれない境遇に陥ると予測され ている。現在の 40 歳代が対象となる将来の高齢社会での労働環境 づくりを論じる場合に，現状そして将来予測される問題を明確にし ておくことが求められる。40 歳代が, 自分たちの将来の高齢期労 働をどのように考えているかを探り, また同時に, 現在の高齢者と 将来の彼らの高踰者像との違いをできるかぎり明らかにすることが
求められる。

技術面から加跉問題を扱う場合に, 社会基盤を無視して論じるこ とはできない5)。労働睘境づくりでは, まず労働の背景に横たわる 問題をとらえる必要がある。そこで, 本論では, 60 歳以上の高㱓 労働者と 40歳代労働者を対象にして幅広く意識調查を行った。既 往の労働環境調查(のように主に青壮年労働者を対象とした調查で なく, 対象を 40 歳代と 60 歳以上の双方の年代層に絞り, 両世代 間に見られる差異から, 高齢期に問題となる作業能力, 労働障壁, 将来の高齢者像, 高齢期の労働環境などについて基本的な検討を行 つた。なお, 高齢労働者の法的定義》は 55 歳以上 65 歳未満の労働 者を示すが, 本論では 60 歳以上の労働者を高㱓労働者とした。

\section{2. 調查方法}

40歳代労働者層（以下，40歳代層と略す）と高齢労働者層（以 下, 高齢者層と略す) に分けてアンケート調查を行った。ここで, 40歳代層を取り上げたのは, 将来さまざまな高齢社会問題にさら される年代層であり, 高齢問題に意識が高いこと, また, 高歯者の 心身機能の衰えをある程度理解できると考えられたためである。本 調查前に高齢者 66 名を対象とした聞き取り調查1),2)を実施した。 内容が本調查結果と重複する箇所が多いため予備調查内容の結果に ついては論じていない。

\footnotetext{
本論文は，文献(1)，(2)において発表した内容に新たな調查内容を加えて再構成したものである。

* 労働省産業安全研究所主任研究官・工博 Chief Research Official, National Institute of Industrial Safety, Ministry of Labour,

**労働省産業安全研究所 特別研究員 $\cdot$ 工博 Dr. Eng.

*** 国立公衆衛生院 室長・医博

Domestic Research Fellow, National Institute of Industrial Safety, Ministry of Labour, Dr. Eng.

National Institute of Public Health, Ministry of Health and Welfare, M.D.
} 


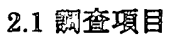

(1) 対象者の属性（年齢，性別，業種，職種，勤務先規模な ぞ），(2) 現在の仕事の内容，(3) 労働可能年齢，(4) 共に作業する 場合の身体機能上の問題, (5) 共に働きたい年齢層, (6) 高龄者の労 伽能力の䛨価, (7) 労傎環境の改善, (8) 40歳頃と比較して気にな る作業環境の変化(高齢者層のみ質問)，(9) 高齢期の労働障壁，(10) 心身機能低下への懸念, (11) 身体の衰えを自覚した年齢（高齢者層 のみ質問），(12)40歳代層の高齢者像，(13) 高齢期労働のあり方 (自由記述式回答)

\section{2 银㿽計圆}

調租地域は東京都下に限定した。

(1) 40 歳代層

(1) 調查対象：従業員 50 人以上の民営事業所の 40 歳代の従業 員, (2) 対象事業所数 : 400 事業所, (3) 抽出台帳 : 平成 8 年事業所 統計, (4) 事業所あたり最大 6人, (5) 調㚗方法: 郵送法, (6) 調査 時期：平成 10 年 3 月 16 日 26日

(2) 高齢者層

(1) 調疽対象: 従業員 30 99人以下の民営事業所の 60 歳以上の 従業員, (2) 対象事業所数: 800 事業所, (3) 抽出台帳 : 平成 8 年事 業所統計, (4) 事業所あたり最大 3 人, (5) 調㚗方法 : 郵送法, (6) 調㚗時期：平成 11 年 2 月 10 日 3 月 8 日

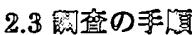

40歳代については無作為に抽出した 400 事業所へ，高齢者層につ いては 800事業所へそれぞれ質問用紙を送付した。後者の配布先事 業所数が 2 倍となっているのは, 60 歳前に退職する労働者がほと んどであり，高齢者の就業者数が少ないためである。配布した調査 票は人事担当者が対象者を選定し, 各事業所の労働者に配布し, 記 裁後に対象者から直接郵送により個別に返送してもらった。

\section{4. 回吹の结舆}

(1) 40 歳代層

(1) 回収事業所效（率）：125事業所（31.3\%）

(2) 回収調㚗票数 : 430 票

(2) 高龄者層

(1) 回収事業所数 (率)：251事業所（31.4\%）

(2) 回収調㚗票数 : 370 票

2.5 サンプル结徍

(1) 40 歳代層

表 1 に示すように 40〜44歳が 178 人と 4 割を, 45〜49歳までが 6割を占め, 平均年齢 44.9 墄, 標準偏差 2.5 歳である。回答者の約 $1 / 4$ は女子である。回答者の属する事業所は, 表 2 に示すようにサ ービス業が 133 人と約 3 割で最も多く, 次いで製造業, 卸壳業とな っている。会社全体の従業員規模は，表 3 に示すように，「50〜 99 人」，「100〜299人」，「300〜999人」がそれぞれ約 2 割を， 「1000人以上」が 3割を占めている。表 4 に示すように, 作業内 容別にみると, 事務的作業が約 4割, 管理的な作業が約 2 割5分, 肉体的作業が約 2 割である。

(2) 高齢者層

表 1 に示すように 60〜64歳が 226 人と 6割を，65～69 歳が約 3 割を占めている。70歳以上が 1 割で, 平均年齢 64.3藏, 標準偏差 3.8 歳である。回答者の約 2 割は女子である。回答者の属する事業
所は, 表 2 に示すように, サービス業が最も多く約 3割を占めてい る。次いで製造業, 建設業となっている。会社の従業員規模は, 表 3 に示すように，「299人以下」が全体の約 8割を,「300人以上」 が僅か約 $15 \%$ である。表 4 の作業内容別回答者数をみると管理的 な作業と事務的な作業を合わせると, 両年代層で共に半数以上を占 め, 次に肉体的な作業の回答者が多い。

婆 140 歳代層と高齢者層の年龄別回答者数

\begin{tabular}{|c|c|c|c|c|}
\hline \multicolumn{2}{|c|}{ 年 齢 } & \multirow[t]{2}{*}{ 回答者数 } & \multicolumn{2}{|c|}{ 比率 (\%) } \\
\hline & & & 男 & 女 \\
\hline 40 & $40 \sim 44$ 歳 & 178 & 74.7 & 25.3 \\
\hline 歳 & $45 \sim 49$ 歳 & 252 & 77.4 & 22.6 \\
\hline 垈 & _誄。 & $(4-30)$ & & \\
\hline 60 & $60 \sim 64$ 歳 & 226 & 81.0 & 19.0 \\
\hline 歳 & $65 \sim 69$ 歳 & 106 & 81.1 & 17.9 \\
\hline 以 & 70 歳〜 & 38 & 76.3 & 23.7 \\
\hline 上 & (計) & (370) & - & - \\
\hline
\end{tabular}

琹 2 業種別の回答者数

\begin{tabular}{|c|c|c|}
\hline \multirow[b]{2}{*}{ 勤め先の業種 } & \multicolumn{2}{|c|}{ 回答者数 } \\
\hline & $\begin{array}{l}40 \text { 歳代 } \\
(n=430)\end{array}$ & $\begin{array}{l}60 \text { 歳以上 } \\
(n=370)\end{array}$ \\
\hline 建設業 & 29 & 44 \\
\hline 裂造業 & 89 & 104 \\
\hline 卸売業 & 57 & 34 \\
\hline 小売業 & 42 & 15 \\
\hline 金融・保険業 & 13 & 10 \\
\hline 不動産業 & 8 & 0 \\
\hline 兽铪・通信業 & 49 & 25 \\
\hline 電気・ガス - 水道他 & 7 & 6 \\
\hline サービス業 & 133 & 106 \\
\hline 無回答 & 3 & 26 \\
\hline
\end{tabular}

臸 3 従業員数別の回答者数

\begin{tabular}{c|c:c}
\hline 企業全体の & \multicolumn{2}{|c}{ 回答者数 } \\
\cline { 2 - 3 } 従業員数 & $\begin{array}{c}40 \text { 歳代 } \\
(\mathrm{n}=430)\end{array}$ & $\begin{array}{c}60 \text { 歳以上 } \\
(\mathrm{n}=370)\end{array}$ \\
\hline $1 \sim 49$ 人 & 23 & 118 \\
$50 \sim 99$ 人 & 90 & 105 \\
$100 \sim 299$ 人 & 86 & 76 \\
$300 \sim 999$ 人 & 98 & 34 \\
1,000 人 以上 & 130 & 24 \\
無回答 & 3 & 13 \\
\hline
\end{tabular}

表 4 作業内容別の回答者数

\begin{tabular}{l|r:c}
\hline \multirow{2}{*}{ 作業内容 } & \multicolumn{2}{|c}{ 回答者数 } \\
\cline { 2 - 3 } & $\begin{array}{r}40 \text { 歳代 } \\
(\mathrm{n}=430)\end{array}$ & $\begin{array}{c}60 \text { 歳以上 } \\
(\mathrm{n}=370)\end{array}$ \\
\hline 肉体的作業 & 85 & 100 \\
事務的な作業 & 157 & 90 \\
管理的な作業 & 103 & 105 \\
営業的な作業 & 59 & 46 \\
研究開発的な作業 & 14 & 12 \\
その他わからない & 7 & 13 \\
無回答 & 5 & 4 \\
\hline
\end{tabular}




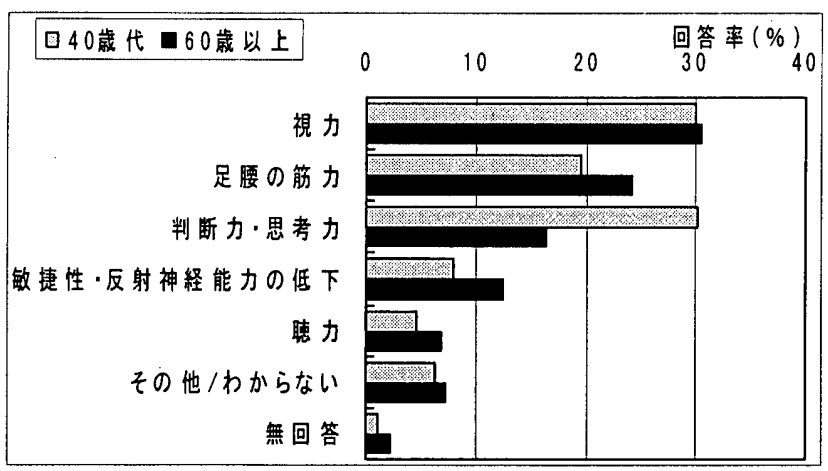

図 1 自分自身が懸念する心身機能の低下 (複数選択可)

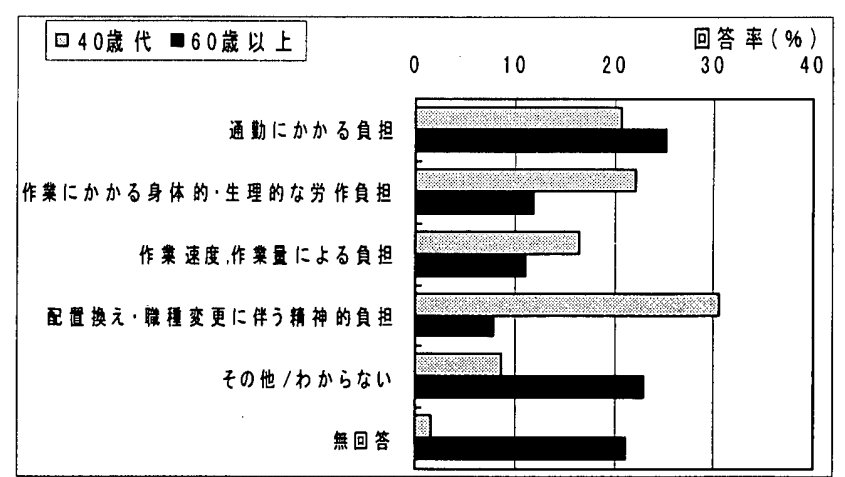

因 2 高齢期の労働障壁

表 5 高齢者が身体の衰えを自覚した年齢

\begin{tabular}{|c|c|c|c|c|c|c|c|c|c|c|}
\hline \multirow[b]{2}{*}{ 年 齢 } & \multicolumn{10}{|c|}{ 衰えを自覚した身体機能 (\%) } \\
\hline & $\begin{array}{c}\text { 視力 } \\
\text { 新聞暨み時 }\end{array}$ & $\begin{array}{c}\text { 聴力 } \\
\text { 電話利用時 }\end{array}$ & 記億力 & $\begin{array}{l}\text { とっさの } \\
\text { 判断力 }\end{array}$ & 作業速度 & 継続性 & 体の動き & \begin{tabular}{|c} 
歩行能力 \\
階段昇降時
\end{tabular} & 足腰の弱さ & 手指の機能 \\
\hline $40 \sim 44$ 歳 & 4.6 & 0.5 & 0.3 & 0.3 & 0.3 & 0.3 & 0.3 & 0.5 & 1.6 & 0.3 \\
\hline $45 \sim 49$ 歳 & 7.3 & 1.4 & 1.4 & 1.1 & 1.4 & 0.8 & 2.4 & 0.3 & 1.6 & 1.1 \\
\hline $50 \sim 54$ 歳 & 22.7 & 4.9 & 7.0 & 5.1 & 3.0 & 2.2 & 4.6 & 6.8 & 4.3 & 2.4 \\
\hline 55〜 59歳 & 32.7 & 12.4 & 28.9 & 16.8 & 14.6 & 20.8 & 23.8 & 24.3 & 25.4 & 12.4 \\
\hline ( $40 \sim 59$ 歳) & $(67.3)$ & $(19.2)$ & $(37.6)$ & $(23.3)$ & (19.3) & $(24.1)$ & $(31.1)$ & $(31.9)$ & $(32.9)$ & $(16.2)$ \\
\hline $60 \sim 64$ 歳 & 14.9 & 9.7 & 23.0 & 19.7 & 17.6 & 18.1 & 21.4 & 29.7 & 27.6 & 13.0 \\
\hline 65～69歳 & 4.6 & 4.9 & 7.6 & 5.7 & 5.1 & 7.6 & 9.2 & 10.0 & 10.0 & 6.2 \\
\hline 70歳以上 & 1.9 & 1.6 & 2.7 & 1.9 & 2.7 & 2.4 & 3.0 & 3.5 & 2.7 & 2.7 \\
\hline ( 60 歳以上) & $(21.4)$ & $(16.2)$ & $(33.3)$ & $(27.3)$ & $(25.4)$ & $(28.1)$ & $(33.6)$ & $(43.2)$ & $(40.3)$ & $(21.9)$ \\
\hline 感じてない & 9.7 & 60.8 & 27.6 & 46.2 & 51.9 & 44.9 & 32.7 & 23.2 & 24.3 & 59.7 \\
\hline 無回答 & 1.6 & 3.8 & 1.6 & 3.2 & 3.5 & 3.0 & 2.7 & 1.6 & 2.4 & 2.2 \\
\hline
\end{tabular}

\section{3. アンケート調查結果及び考察}

\section{1 心身機能の衰えと高齢期の労傎障壁}

「自分自身が懸念する心身機能の低下」に関する集計結果を図 1 に示す。世代間（40歳代層と高齢者層）の回答結果に高度な有意 差が見られる $\left(\chi^{2}(6)=22.2 ; \mathrm{p}<0.05\right)$ 。各選択項目ごとに見ると, 40歳代は「視力」，「判断力・思考力」が約 3割となっている。一 方, 高歯者層では, 「視力」，「足腰」の順で高く，25〜30\%を占 めている。両世代層に共通して「視力」の衰えが高い割合を示して いる。「判断力・思考力」に関しては世代間で差が最も大きく, 40 歳代層が，高齢者層の約 2 倍となっている。40歳代は「視力」の 衰えと同時に，「判断力・思考力」の衰えも懸念している。

高齢者のみを対象にした質問で，自分自身の心身機能（歩行能 力,視力,聴力など）が衰えたと自賞した年齢に関する回答結果を, 表 5 に示す。調查対象が 60 歳以上の労働者であることから，60歳 を境に合計值も 40〜59 歳と 60歳以上に分けて表中に併記してあ る。40５9歳層の值から，大きさ順に列記すると，「視力」，「記憶 力」,「足腰」,「歩行能力」,「体の動き」,「継続性」,「判断力」, 「作業速度」，「聴力」，「手指の機能」となる。ほとんどの心身機 能の衰えが 55〜59歳層から緩やかに始まっているが，「視力」だ けは早く，40歳から緩やかに始まり，40歳から54歳までを合計し た值で見ると約 3 割5分も衰えている。これは，上記の図 1 で示す
ように，高齢者層が「視力」の衰えを最も懸念している結果と一致 する。「聴力」で「感じていない」とする割合は約 6 割と最も高 い。図 1 でも「聴力」の割合が高くない。しかし，明らかに生理的 高音域の聴力が劣っている 75 歳以上の後期高齢者（平均年齢 81.3 歳) の聴力実態調查結果8)を見ても「電話の声」で「特に問題な い」が $54.2 \%$ となている。「視力」と異なり,「聴力」では,こ のような結果になる理由として，聴力の衰えが作業にさほど影響を 与えていないか, 聴力の衰えに本人自身が気づいていないと考えら れる。主観的な判断による調査法の問題点とも言える。

「60歳過ぎまで働き続ける上で最も大きな障壁は何か」に関す る質問の集計結果を図 2 に示す。世代間に高度な有意差が見られ る $\left.\left(\chi^{2}(5)\right)=160.0 ; \quad \mathrm{p}<0.05\right)$ 。高齢者層の場合，「通勤にかかる負 担」が最も大きくて，高齢者には通勤負担が大きな労働障壁である ことが分かる。また，「分からない」と「無回答」の割合も高い。 これは，高龄者にとっては労働障壁となるものが，与えられた選択 肢に見いだせなかったとも理解される。40歳代層の場合は, 「配 置換えなどに伴う精神的負担」が最も高く，次いで，「身体的・生 理的な労作負担」，「通勤にかかる負担」である。40歳代層にとつ ては, 回答結果は類推によるために, 現在かかえている問題に強く 影響を受けることから，40歳代層では，「配置換えなどによる精 神的な負担」が現時点でも大きいと理解すべきであろう。 


\begin{tabular}{|c|c|c|c|c|c|c|c|c|}
\hline \multirow{2}{*}{ 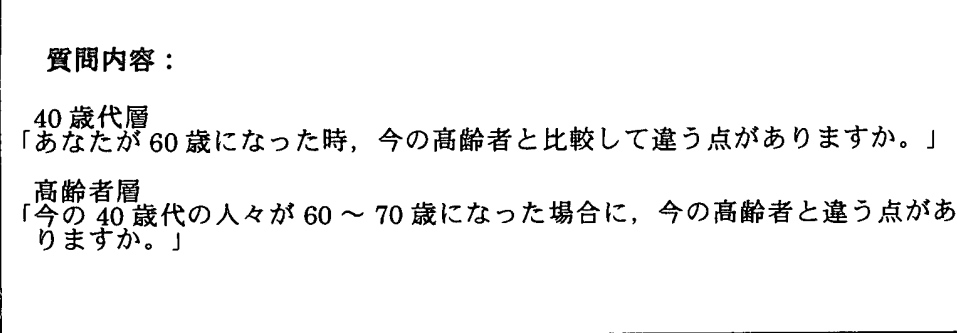 } & \multicolumn{4}{|c|}{$\begin{array}{l}40 \text { 歳代首による自分自身の } \\
\text { 高跨者像 } \\
\qquad(n=430)\end{array}$} & \multicolumn{4}{|c|}{$\begin{array}{c}60 \text { 歳以上による } 40 \text { 歳代の } \\
\text { 人々の将来の高齢者像 } \\
\qquad(\mathrm{n}=370)\end{array}$} \\
\hline & $\begin{array}{l}\text { 恚 } \\
\text { 䍗 } \\
(\%)\end{array}$ & 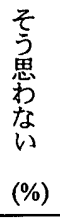 & $\begin{array}{l}\text { 変 } \\
\text { 足 } \\
\text { ta } \\
\text { (\%) } \\
\end{array}$ & 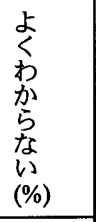 & $\begin{array}{l}\text { そ } \\
\text { 惫 }\end{array}$ & $\begin{array}{l}\text { そ } \\
\text { 崽 } \\
\text { 市 } \\
\text { な } \\
\text { W } \\
(\%)\end{array}$ & $\begin{array}{l}\text { 変 } \\
\text { 足 } \\
\text { な } \\
\text { 小 } \\
\text { (\%) }\end{array}$ & 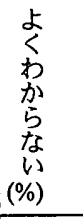 \\
\hline (1) ワーブロなどの使用にもっと慣れている. & 78 & 8 & 10 & 4 & 84 & 6 & 3 & 7 \\
\hline (2) 情報機器の使用に慣れている（パソコン, インターネットなど） & 76 & 9 & 10 & 5 & 85 & 7 & 3 & 5 \\
\hline (3) 年功序列の一律貨金でなく能力別赁金, 職務内容別貨金体系に慣れている & 58 & 15 & 14 & 13 & 69 & 5 & 8 & 18 \\
\hline (4) 高齢者が現場でも戦力となり活躍している. & 41 & 14 & 35 & 10 & 35 & 22 & 23 & 20 \\
\hline (5) 働く意欲が高い. & 37 & 12 & 41 & 11 & 22 & 35 & 23 & 20 \\
\hline (6) 若い上司ともうまくやっていける. & 35 & 16 & 35 & 14 & 24 & 26 & 22 & 28 \\
\hline (7) 健康で元気だ. & 26 & 17 & 46 & 11 & 20 & 33 & 27 & 20 \\
\hline (8) 根気がある. & 25 & 21 & 43 & 11 & 12 & 48 & 22 & 18 \\
\hline (9) 足腰や腕の筋力が優れている. & 16 & 25 & 52 & 7 & 8 & 46 & 25 & 21 \\
\hline (10) 聴力が倀れている. & 12 & 17 & 62 & 9 & 8 & 27 & 35 & 30 \\
\hline (11) 視力（近点; 夜間; 動体視力）が優れている. & 10 & 25 & 56 & 9 & 7 & 41 & 27 & 25 \\
\hline
\end{tabular}

\subsection{0 瓷代層の高路者像}

40歳代層の将来の高齢者像を高齢者層と対比させることにより 意識差を調査した。表 6 にその集計結果を示す。「そう思う」と 「そう思わない」について, 世代間の差を検定すると, (1)ワープロ と(2)情報機器に関してのみ世代間に一致性が見られる（それぞれ $\chi^{2}(1)$ は 1.91と1.94; p>0.05)。「よくわからない」と回答した割 合は, (1)と(2)の項目を除いて，高齢者層が約 2 ３割でやや高い。 このことから高齢者層にとって，40歳代の高齢者像を具体的に類 推するのがやや難しいと思われる。

質問項目(1)，(2)に，「そう思う」と回答した割合は 8割前後に及 ぶ。その他に，「そう思う」の回答割合が高いのが, (3)能力別賃金 で, 40歳代層が約 6割, 高齢者層が約 7割である。次に, (4)現場で も戦力でそれぞれ約 4割と 3割5分である。競争原理に基づくグロ 一バル化や情報化されつつある社会の到来を感じているようであ る。

逆に，「そう思う」と回答した割合が低いのは，高齢者層につい ては，心身機能に関わる質問内容で，(7)健康，(8)根気，(9)筋力，

(11)聴力, (11)視力である。これは, 現在の高齢者は今の 40 歳代層の 将来の高齢者像で身体機能面では否定的に回答していることを示し ている。

40歳代層の回答結果によれば, 彼らの将来の高齢者像では, 今 の高齿者と「変わらない」とする割合が, 各質問項目の全てについ て高齢者層を上回っている。40歳代層は自分自身が高齢者となっ ても，現在の高齢者と比較してそれほど大きな変化はないと考えて いるようである。

将来の高齢者像で両年代層が一致した質問項目(1)と(2)の結果から 判断して, 多くの事業所で情報ネットワークの発達により, 在宅労 働型の SOHO（Small Office Home Office）的な形態が現れ, 自由な
通勤, 勤務時間などが普及する社会の到来も想像されているようで

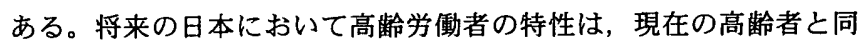
じでなく変動してゆくと考えるのが妥当である。

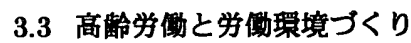

（1）最大労働可能年踰：「何歳まで働けるか」との質問に対して, 図 3 に示すような結果になった。世代間に高度な有意差が見られ る $\left(\chi^{2}(7)=246.6 ; \quad p<0.05\right)$ 。70歳以上でも働けるとする回答結果 (「70歳まで」，「75歳まで」，「80歳まで」，「健康ならばいつま でも」の合計值）は，40歳代層が 19.6\%と低いのに対して，高齢 者層が $65.9 \%$ と非常に高い。一方，仕事をしていない 60 歳以上の 企業退職者を対象にした調查結果9) (1998年1月実施)でも, 回答者 の年龄が高まるにつれて希望引退年齢が高くなる傾向が見られた。 日本人の勤労意欲は欧米と比較すると高いと言われているが，40 歳代の意識も年をとるにつれて将来高くなると思われる。なぜなら ば, 最大労働可能年齢で見られるように, 高齢者側で高まる傾向が あるためである。

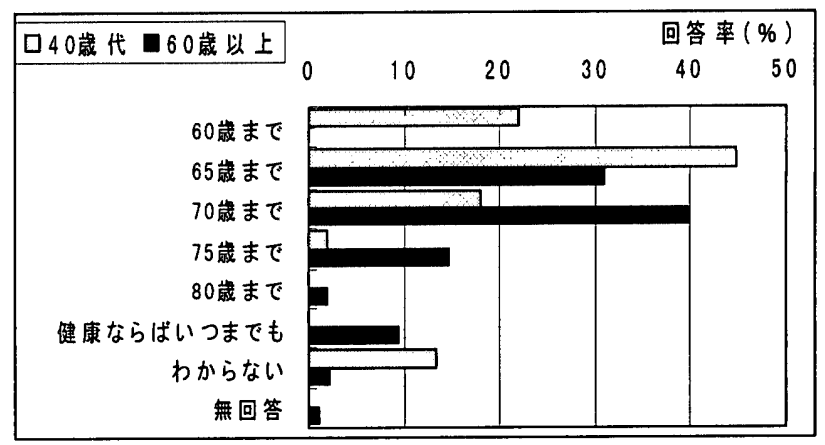

図 3 最大労働可能年齢 


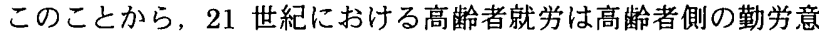
欲には問題なく，雇用者側の受け入れ体制と㕍用環境の整備がその 決定的要因となると考えられる。

（2）共に働きたい年龄グループ：「高齢期に共に働きたい年齢グル 一プ」の集計結果を図 4 に示す。世代間に有意差が見られない $\left(\chi^{2}(5)=5.4 ; \mathrm{p}>0.05\right) 。 \supset ま り ，$ 年齢層にかかわらず差がなく同じ傾 向が見られる。「必ず混在するグループ」と「どちらかと言うと混 在するグループ」の選択結果を合わせると，双方のそれぞれ約 8割 が，「混在するグループ」での労㗢を望んでいる。高齢者層にかか わらず，40歳代層も自分自身の高齢期においては，共に働く労働 者の年齢層が混在した舞境で働くことを大多数が希望している。

（3）青壮老が共に作業する場合の問題となる心身機能 : 混在グルー プで高齢者と共に作業するようになった場合に，高齢者のどの作業 能力が問題になるかを，双方に尋ねた。その集計結果を図 5 に示 す。世代間に高度な有意差が見られる $\left(\chi^{2}(11)=73.9 ; \quad \mathrm{p}<0.05\right)$ 。 40 墄代層では,「記億力の低下」が最も大きな問題として上げられ た。また,「小さな目盛, 数字などの読みにくさ」,「体の動きが遅 い，敏揵性の衰え」，「とつさの判断力の衰え」，「作業速度の遅 さ」などがほほ均等な割合で示されている。高齢者層は,「小さな 目盛，数字などの読みにくさ」が最も高い。次いで，「記憶力の低 下」,「足腰の弱さ」になっている。

一方, 図 1 と表 5 の結果からみると,「自分自身で喼念する心 身機能の低下」でも「視力」と「足腰」と「判断力・思考力」が高 い割合を示している。表 5 の自覚年齢でも「視力」，「記億力」，

「体の動き」が高い割合を示し, 同様の結果を示している。また, 既往研究10)では，眼調節能のなかでも近距離視力の衰えに関する 名古屋市近郊の自動車組立工場の男子労働者約 9000 人の追跡調查 結果によれば，40 歳から急激に衰えはじめ，50 歳から変化が少な くなることが報告されている。この傾向は出生コホートや時代によ る影響が少ない。このような調查結果からみても高龄社会対応の労 働環境づくりでは, 足腰や歩行, 中枢能力である判断力・思考力, 記憶力などの衰えと同時に, 特に, 視力の衰えと視環境への配慮が 重要であると推察される。

（4）労働曼境の改善：「高踰期に要望する労働環境の改善」に関す る集計結果を図 6 に示す。両世代間に高度な有意差が見られる $\left(\chi^{2}(8)=67.2 ; \mathrm{p}<0.05\right)$ 。40歳代層が求めるのは, 「勤務時間の短縮」 が最も高く, 次いで「仕事量やノルマの削減」である。高龄者層で は,「勤務時間の短縮」が最も高い。次に,「時差通勤」と「職場環 境の改善」になっている。共通してワークロードの軽減を希望して いる。一方，50藏以上の労働者を対象にした調査結果11)によれば, 労働者が望む高路労働への配慮項目は，「仕事の分担を調整する」 が約 6割で最も多く, 次いで「仕事の量を調整する」が約 5割, 「労働時間を短縮する」が約 3 割，「休暇を取りやすくする」が約 3割で，「勤務時間を調整する」が約 2 割となっており，「作業睘境を

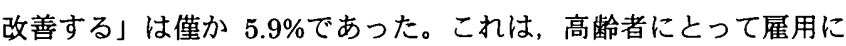
かかわる問題に関心が高いことを示している。

高齢者層のみへの質問で，「40歳代の頃と比較して，60歳を過 ぎてから特に気になる作業睘境」に関する集計結果を図 7 に示 す。「非常に気になる」と「気になる」と「少し気になる」の集計

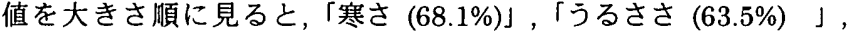

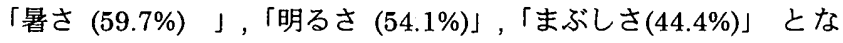
る。環境要因である温熱と騒音で高く，照明でやや低い傾向となっ ている。今後は更なる検討をしてゆく必要がある。

\section{4 自由記述の内容の分析及び考察}

高齢期労働のあり方を把握するために，40歳代層と高秢者層の 両方に，高齢期労働にとって「良い労働環境」とはどのような環境 であるかを，自由記述してもらった。40歳代層には，自分自身が 60 歳以上になった場合を想定して記述することを求めた。

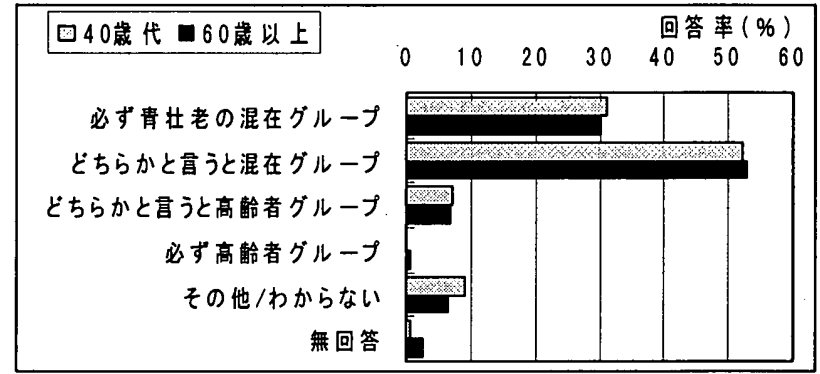

図 4 高啮労働期に共に働きたい年齢グルーブ

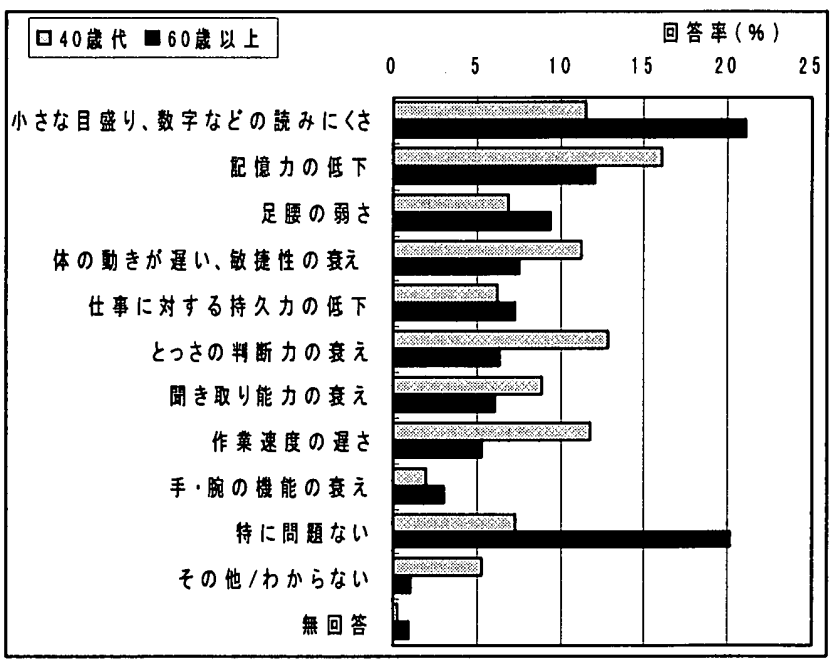

図 5 青壮老が共に作業する場合に問題となる心身機能

(複数選択可)

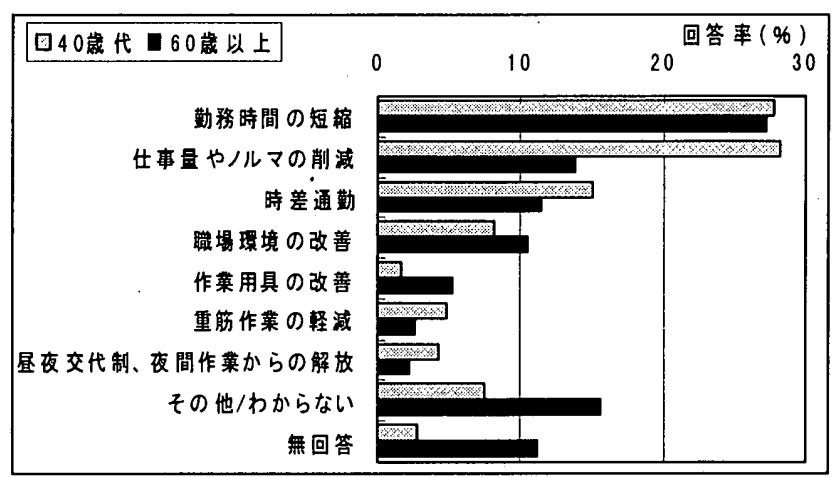

図 6 労働環境の改善(複数選択可) 


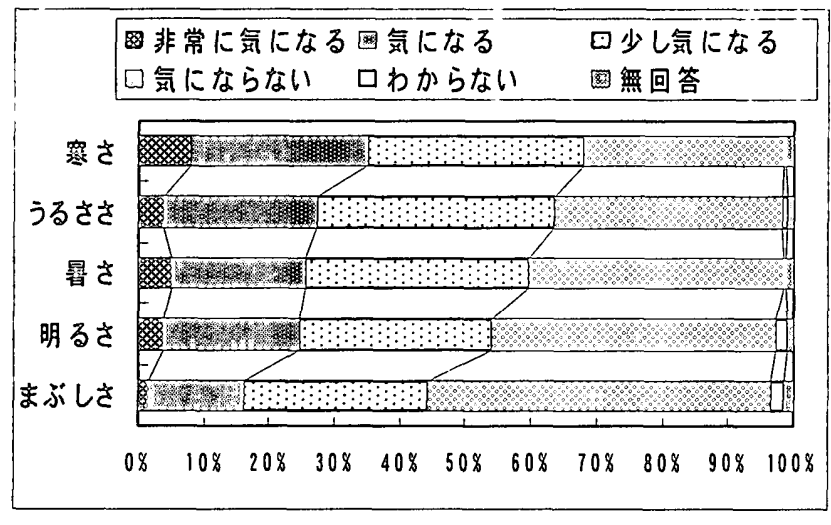

图 7 高龄になるほど気になる作業環境

自由記述による調㚗の趣旨は，高齢期労働に対するより良い労働 環境づくりのための必要条件を幅広く抽出するためである。この自 由回答内容の分析を通して, 両年代層間による意識差について考察 を行った。ただし，自由に記述する内容は，自分自身にとって最も
関心のある内容，訴えたい内容となる傾向があると思われる。

(1) 記述内容の分類と結果

自由記述の内容から, 高齢者層 133 人から 171 件の項目が，40歳 代層 194人から 279件の項目が抽出された。その中で, 表現法が異 なるが, 内容が同一であるとみなし得る項目ごとにグループ化し， 40項目にまとめた。その分類結果を 40歳代層と高齢者層の意見に 分けて図 8 に示した。同図の中の数值(\%)は，その項目を記述した 回答者数をその年代層の全体数で除した。数値が高いほどその項目 の要求度が高いことを意味している。また，この分類に偏りが生じ ないように3人によって作業を行った。

自由記述内容を，3 つに大別した。そのなかでも「就労条件」に 関する記述が多いのが特徴的である。中分類項目は 7 つに分類し て, 花や緑があふれる環境, 明るい照明環境, 作業スペースの確保 などの「建築施設・設備」, 高齢者の差別のない職場, 青壮老の混 在職, 明るく楽しい職場などの「職場の等囲気」, 労働時間や出勤 日数を短縮してほしいという「就労時間・日数, 休㗇」, 経験を生 かせる専門的仕事, 自分の能力・体力に応じた仕事の希望などの 「仕事の内容」，定年制，年金制などに関する「制度」，そして

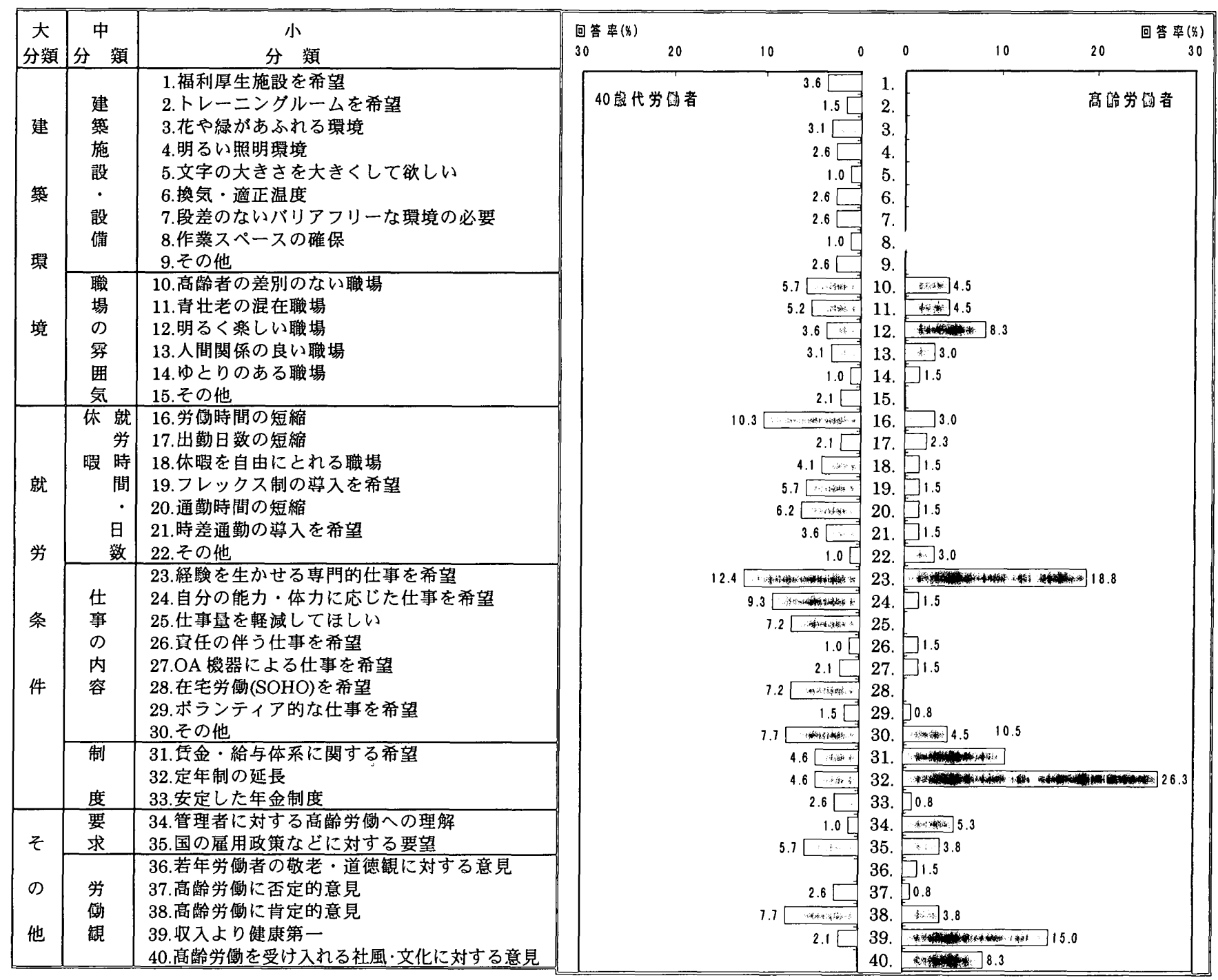

图 8 高齢期労働のあり方についての自由回答 
管理者・国への「要求」と「労働観」である。

回答率が高い項目は，40 歳代層では「仕事の内容」に関する項 目で，高秢者層では「制度」に関する項目である。小分類項目別に 構成割合を見てみると，40歳代層の場合，「経験を生かせる専門 的な仕事」や「自分の能力・体力に応じた仕事」，「仕事量の軽 減」がそれぞれ $12.4 \%, 9.3 \%, 7.2 \%$ となっており，高齿者層の場 合は，「定年制の延長」が $26.3 \%$ ，「賃金・給与体系に関する希 望」が $10.5 \%$ とっている。

(2) 40 歳代層と高齢者層との意識差

図 8 に示す 7 つの中分類項目に関して，世代間の有意差を検定 してみると，高度な有意差が見られる $\left(\chi^{2}(6)=82.4 ; \mathrm{p}<0.05\right)$ 。

40歳代層の場合,「仕事の内容 $(48.5 \%) 」 の$ 回答率が最も高いこ とから，40歳代層は，高齢期労働では，「仕事の内容」を重視して いることが分かる。例えば, 労働・通勤時間の短縮, 経験を生かせ る専門的な仕事や在宅労働(SOHO)などを望んでいる。高龄者層の

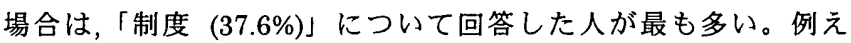
ば，「年齢を理由に給与を減額してほしくない」，「能力・資格が あれば年齢関係なくいつまでも働きたい」などの内容であった。そ の中でも「定年制の延長」への希望が最も高かった。

40歳代層の場合に, 福利厚生施設, 照明, 換気, 作業スペース などの「建築施設・設備」に関心を示しているが, 高齢者層の場合 では，この内容に関する回答が全く見られない。このことは，規模 の比較的に小さな事業所で働く高齢者が過不足なく恵まれた建築的 環境にいると理解するのでなく, 高齢者には労働環境へ目を向ける 余裕がなく, 現実の㕍用状況の厳しさが反映されていると理解すべ

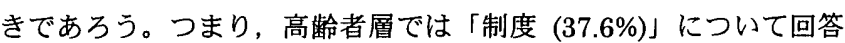
した人が最も多いことから見ても分かるように, 現状の高齢者は, 建築環境へ配慮するだけの心のゆとりがなく，㕍用安定のための制 度的な改善を強く望んでいると推察される。

\section{4. 論考}

\section{1 労傎環境づくりと共生思想}

21世紀では，従来の均一性を重視する社会から脱却して，個性 を重視する社会に移行すると言われている12),13)。そこでは，混在 した中で互いの利害得失などを認識した上での新たな共生関係の構 築が求められている。図 4 に示された結果からも青壮老が共に働 くことを望んでいる。労働環境づくりにおいても「共生」が将来の 重要なキーワードとなるであろう。作業環境づくり・支援機器づく りでは，高齢者だけが専有する環境・用具を整えるのでなく，出来 る限り幅広い年齢層が利用できるようにするのがこれからの課題で ある。障害者の生活の阻害要因を取り除くバリアフリーと称される 設計思想では, バリアーを除去することに主眼を置き, 他の人々と の「共生」にあまり重きを置いていない。そのために，共有して使 えるものが多いとは言えない。しかし「共生」を志向したユニバー サルデザイン思想14)により，高齢者だけでなく，若い作業者も含 めて, 年龄差なく誰にとっても安全で働きやすい労働環境づくりを 目指すべきであろう。

\section{2 総体的な労俉環境づくり}

高齢社会対応の労働環境づくりを検討する前に, 高跲者雇用に関 する根本的な社会的・制度的な問題がある。現在, 雇用されている
高齢者にとって, 㕍用の安定が最重要な課題となっている。この根 本的な課題が年龄制限撤廃などの形で社会的コンセサンスを得て解 決された上で, 真に「共生」できる労働環境づくりが行える。高榆 社会における労働環境づくりは, 医療と福祉を含めた地域の支援体 制づくりと有機的に連携してゆくことが求められている。しかし, 現在は個別の事業所内の改善・工夫に留まっており, 労働人口が高 齢化してゆくことに対して産業界全体で十分な対応ができていると は言えない。将来の少子・高榆化の時代を見すえ，将来起こりうる 労働環境の変化を踏まえ，「共生」を目指した労働環境づくりのた めの建築的支援も含めた総体的な取り組みが求められる。

21世紀には年金支給開始年齢の引き上げがせまっており，高齢 労働者を受け入れる社会環境づくりが緊急に求められている。高龄 者の就労機会の拡大は, 結果的には公的な福祉関連費用之個人の経 済的な負担の軽減につながる。このように, 高齢者を含めた「共 生」を目指した労働環境づくりは, 単独で存在する問題でなく, 鎖 で慗がった高齢社会問題の一つとしてとらえる必要がある。

\section{5. 結語}

高秢社会での労働環境づくりのあり方をアンケート調查結果から 考察して論じた。高齢期の労㗢について，40 歳代層と高齢者層の 労働意識を対比しながら検討し次のような結果が得られた。

・高齢者層と同様に, 40 歳代層の多くが高齢期には, 青壮老の混 在するグループを好む。

- 40 嘁代層と高齢者層が共に作業する場合、40 歳代層から見た高 齢者層の身体機能の問題点は，「記憶力」，「とっさの判断」， 「作業速度が遅い」が挙げられ、高齢者首は「小さな文字が読めな い」，「記億力」に関して懸念を自分自身で認めても 40 歳代層と の労働は「問題ない」としており、世代間に認識差が見られる。

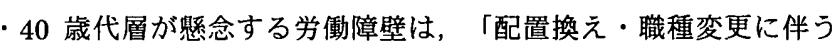
精神的な負担」であり、高龄者層は「通勤にかかる負担」を最も 懸念している。

・年齢にかかわらず, ワークロード軽減への配慮を求めている。職 務管理面, 作業支援機器や作業方法などへの配慮が必要である。

•40 歳代層の将来の高齢者像は, パソコン, ワープロに慣れ, 企 業で高齢者層が戦力となって働いていると考えられている。一 方, 高踰者層の回答結果によれば, 40 歳代層の将来の高齢者像 が今の高齢労働者と比して身体機能（健康, 筋力, 聴力, 視力) が特に優れるようになるとは言えない。特に，「根気」，「筋 力」，「視力」に関しては低い評価がなされている。

・ 心身機能低下のほとんどが 55 歳頃から始まっているが, 「視 力」だけは早く, $50 \sim 54$ 歳から衰えている。逆に，「聴力」の 衰えは，「感じていない」とする高龄者の割合が最も高い。 ・40 歳代層の場合, 福利厚生施設, 照明, 換気, 作業スペースな どの「建築施設・設備」に高い関心を示していたが，高齢労働者 はこの内容に関する回答が全く見られない。高齢労働者は「定年 制／給与」の改善を強く望んでいる。

調查結果から, 将来の高踰者は, 青壮老が混在した職場で働くこ とを好み，勤労意欲も高く，今の高齢者より社会の情報ネットワー ク化に適応していると推察される。このように，「高齢者」を固定 観念で見るのでなく，「高路労働者」と言う言葉の意味が, 時代の 
移り変わりと共に流動してゆくといった見方をする必要がある。 労僖睘境づくりでは, 足腰の筋力低下に対応してワークロードを 低減する方向の支援的設計と, 視力の衰えに対応した建物内の文字 サイズや明るさなどの視環境への配慮が特に求められる。労针環境 ブくりでは，体想室の充実なども望まれるが，労働者の介讙支援之 いった面から託老所の職場内設置, 高龄者の入居も想定した独身察 の設置といった面から新たな発想が必要となるであろう。本報の基

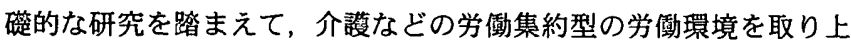
げて, 建築的な面からの青壮老が混在する労憉環境で改善すべき点 などについて具体的に検討しているところである。

本研究は，6省庁と民間の 24 研究機関が参加した科学技術仃科学 技術振興調撉费の生活基盤研究に属する「高齢社会における製品。 環境などのユニバーサル化に関する研究」の一部として実施した。

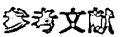

1) 永田久雄 : 高踰社会対応の労㑬瑟境づくりに関する意識調查,産業・組 識心理学会第 14 回大会, pp.130 132, 1998.8

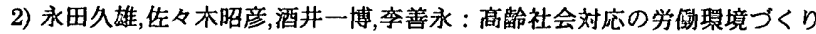

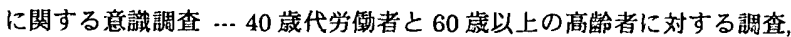
労㑬省産業安全研究所所報, NIS-RR-98, 1999

3）高年齢者㕍用開発協会：人口の年龄满造の推移と見通し，p26，高齢社会 統計要㯺, 1998

4) 経済企画仃: 国民生活白書「中年」その不安と希望，1998.12

5) Forzard,J.L.: Aging and technology - a developmental view, Proc. Human Factors Ergonomic Society Annual Meeting, Vol. 40th, No. 1, pp.138-140,1996

6) 労湖大臣官房政策調査部:労傎環境禂査報告(平成 8 年), 1997.10

7) 労僖省令 : 高年齢者等の㕍用の安定に関する法律施行規則,労倒省令 24 号, 1971.9 .8

8）楢村裕美：高龄者の聴力の実態一老人保健施設入所者における調㚗， Audiology Japan, Vol.40, pp.713 718, 1997

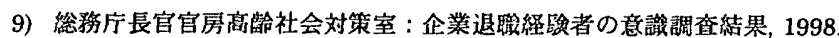

10）下方浩史：继断的追跡調查デー夕による視力・眼調節能の加齢変化の桧 討(93A2208-3),厚生省厚生科学研究費補助金長寿科学棇合研究 平成 6 年度研究報告,pp361-365, 1995

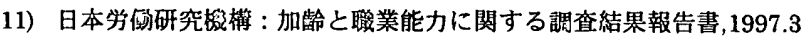

12）黒川紀章：新共生思想, 徳間書店, 1996

13）松田裕之：「共生」とは何か...㩁取と就争をこえた生物どうしの第三の 関係，現代書館, 1998.5

14）古攧 钽絽 : ユニバーサルデザインとはなにか, 都市文化社, 1998 